Annals of Plant and Soil Research 23(1): 93-98 (2021)

https://doi.org/10.47815/apsr.2021.10036

\title{
Effect of crop regulation practices on spike and corm yield of gladiolus (Gladiolus hybrids Hort.) cv Sarala
}

\section{R. MARY RUBY SHYLA AND S.RAMESHKUMAR}

\begin{abstract}
Department of Horticulture, Faculty of Agriculture,Annamalai University, Annamalai Nagar,Tamil Nadu, India, 608002
\end{abstract}

Received: November, 2020; Revised accepted: December, 2020

\begin{abstract}
Standardization of the crop regulation practices is vital for spike and corm yield maximization in gladiolus (Gladiolus hybrids Hort.). Hence, a field experiment was conducted in factorial randomized block design with three replications at Annamalai University, Annamalai Nagar, during 2019 with the objective to maximize the spike and corm yield of gladiolus by growth regulators and leaf regulation practices done after spike harvest. The gladiolus $\mathrm{cv}$. Sarala was tested with 15 treatment combinations comprising growth regulator treatments of corms viz., 100ppm $G A_{3}\left(G_{1}\right)$, 150ppm $G A_{3}\left(G_{2}\right)$, 100ppm IAA(G $\left.G_{3}\right)$, 150ppm IAA $\left(G_{4}\right)$, and Control $\left(G_{5}\right)$ and leaf regulation practicesviz., harvesting spike leaving all leaves $\left(L_{1}\right)$, harvesting spike with three leaves $\left(L_{2}\right)$, and clipping leaves at $20 \mathrm{~cm}$ above the base $\left(L_{3}\right)$. The results revealed that the growth regulator treatments, given to corms significantly influenced the growth, flowering, and spike yield of gladiolus. Corm soaking treatment of GA3@150 ppm evinced the best treatment in respect of growth, flowering, and spike yield of gladiolus. Though, the effect of leaf regulation practices on growth and flower yield were insignificant, but their influence in corm yield was significant. The interaction of growth regulator soaking of corms with leaf regulation practices significantly influenced the spike and corm yield. The maximum spike (1.01) and corm yield (1.94) were observed with Corm soaking of GA3@150ppm and harvesting of spikes with three leaves. Leaf regulation by clipping of leaves at $20 \mathrm{~cm}$ above the base $\left(L_{3}\right)$ had negative influence on corm growth when compared to harvesting of spikes leaving all leaves $\left(L_{1}\right)$. The maximum corm diameter $(3.25 \mathrm{~cm})$ and corm weight (25.4g) were observed with $150 \mathrm{ppm} \mathrm{GA}_{3}$ and harvesting spikes with three leaves. The least corm diameter $(2.08 \mathrm{~cm})$, number of corms per plant (1.22) and corm weight $(17.3 \mathrm{~g})$ were recorded with control treatment with cutting leaves at $20 \mathrm{~cm}$ above the base.
\end{abstract}

Keywords: Gladiolus, corm soaking, GA3, IAA, leaf regulation

\section{INTRODUCTION}

Gladiolus, a popular flowering plant in international cut flower trade is grown throughout the world in a wide range of climatic conditions and it belongs to the family Iridaceae. Though, it was brought under commercial cultivation later decades of sixteenth century, its cultivation in south India is very scanty at certain pockets. In India, it is cultivated in West Bengal, Himachal Pradesh, Sikkim, Karnataka, Uttar Pradesh, Tamil Nadu, Punjab and Delhi over an area of 11.85 thousand ha 2015(NHB,2020). Though, there are over 30,000 varieties of gladiolus available, only few are commercially cultivated in many parts of the world. Commercial cultivation of gladiolus primarily depends on the quality of spikes as well as the quality of corms. Hence, the crop management practices should focus on production of good quality marketable spikes with at least 13 florets to meet both local and international standard and production of jumbo size corms. Achieving marketable quality standards in spikes and corms can be approached by addressing the nutrient requirement and growth regulation practices. Poor multiplication rate, extended dormancy in corms, and slower growth rate of cormels restrict their immediate use in the following season and cause lack of planting material. These are the hindering factors for year round production of gladiolus in coastal areas.

Corms are the important factors which govern the growth and development of gladiolus, further, the physiological functions inside the corms are controlled by plant growth regulators (Sudhakar and Ramesh Kumar, 2012). Plant growth regulators are the organic chemical compounds which modify or regulate physiological processes in an appreciable measure in plants when used in small concentrations. In general the plant growth 
regulators play an important role and are being used for breaking dormancy and production of quality corms and spikes in gladiolus. This also results in high cost of corms, which is often higher than the sale price of the spike produced by that corm. Application of $\mathrm{GA}_{3}$, (Panwar et al., 2006) IAA were found best in early initiation of spike and for higher spike yield. Dipping of corms in the $\mathrm{GA}_{3}$ solution breaks the dormancy and promotes the sprouting of lateral buds resulting in splitting (division into two or more daughter corms) of corms and thus increasing the number of corms and cormels per plant (Memon et al., 2016). Application of growth regulators by foliar means and corm soaking was studied and found to increase the growth and quality of spikes in gladiolus at varying levels. Enhanced growth and spike production was observed due to application of growth regulators like $G_{3}, I A A$, NAA in gladiolus by Sudhakar and Ramesh Kumar (2012), Neha Chopde et al., (2012) and Priyanka and Saravanan (2019). These growth regulators play a vital role in apportioning the photosynthates towards the enhanced growth and spike production. The corm growth and quality of gladiolus is decided by the physiological process that occurs after spike harvest in a plant. A growth regulation process that stimulates apportioning the residual carbohydrates in the shoots portion of the plants after the spike harvest, is not yet commercially tried in gladiolus. Leaf regulation practices after spike harvest apparently helped to conserve the plant's energy and metabolites that ultimately enhanced the multiplication of corms and cormels. Removal of spike with three leaves treatment was found effective in cormel production. The energy required for flower production may also be diverted towards corm and cormel development by removing the spike (Memon et al., 2016). Improved techniques used to promote corm and cormel production in Gladiolus are removal of flower spikes, leaf clippings (Memon et al., 2009) and manual removal of apical buds. Hence, the present study was carried out to evolve a crop regulation practice by combining application of growth regulators and leaf regulation practices to maximize spike and corm yield of Gladiolus (Gladiolus hybrids Hort.) cv. Saralaunder coastal region of Tamil Nadu.

\section{MATERIALS AND METHODS}

The experiment was carried out in factorial randomized block design during the year 2019 in Annamalai University, Annamalai nagar, Tamil Nadu. Corms of Sarala were collected from commercial floriculture units in Kalimpong. These corms were planted in ridges and furrows made at a spacing of $45 \mathrm{~cm} \times 15 \mathrm{~cm}$ in a plot size of $2 \mathrm{~m} \times 2 \mathrm{~m}$ dimension. The soil of the experiment site is sandy loam having the $\mathrm{pH}$ range of $7.0-7.5$. Vermicompost $\left(25 \mathrm{t} \mathrm{ha}^{-1}\right)$ was applied 15 days prior to planting during land preparation. Standard package of practices were adopted throughout the experiment to grow a healthy crop. Growth regulator treatments to corms at five levels viz., 100ppmGA $\mathrm{A}_{3}\left(\mathrm{G}_{1}\right)$, 150ppmGA $\mathrm{A}_{3}\left(\mathrm{G}_{2}\right), \quad 100 \mathrm{ppm} \quad \mathrm{IAA}\left(\mathrm{G}_{3}\right), \quad 150 \mathrm{ppm}$ IAA $\left(G_{4}\right)$, and Control $\left(G_{5}\right)$ as one factor and leaf regulation practices at three levels viz., harvesting spike leaving all leaves $\left(L_{1}\right)$, harvesting spike with three leaves $\left(L_{2}\right)$, and clipping of leaves at $20 \mathrm{~cm}$ above the base $\left(L_{3}\right)$ as second factor are combined to form 15 treatment combinations. Growth regulators were applied as corm dipping before planting. The leaf regulation practices were adopted as per treatments during spike harvest. For $L_{1}$, only spikes were harvested leaving all the leaves intact with plant. The spikes were harvested at the first floret opening stage. For $L_{2}$, the spikes were harvested along with three leaves attached with them. For $L_{3}$, the spikes were harvested leaving all the leaves attached with the plant and the leaves were immediately clipped leaving $20 \mathrm{~cm}$ above the base of the plant. The corms were harvested at 45 to 50 days after spike harvest based on the soil moisture condition. Observations on various morphological parameters including plant height, number of leaves per plant, leaf length, leaf width, days to spike emergence, spike length, number of floret per spike, flower length, flower diameter, diameter of corm and number of cormels were recorded periodically. The data were analysed as per the procedure given by the Panse and Sukhatme (1967). Mean and critical difference for each character was computed to derive meaningful conclusion. 


\section{RESULTS AND DISCUSSION}

\section{Growth characters}

Results revealed that the growth characters were significantly influenced by the growth regulator application. The days taken for corm sprouting was observed the earliest of 7 days in $150 \mathrm{ppm} \mathrm{GA}_{3}\left(\mathrm{G}_{2}\right)$. It took more than 8 days in IAA treatments and 10 days in control (Table 1). Among the growth regulators, the highest mean of growth parameters viz., plant height $(111.0 \mathrm{~cm})$, leaf length $(76.9 \mathrm{~cm})$, leaf area $\left(128.5 \mathrm{~cm}^{2}\right)$ and DMP $\left(41.4 \mathrm{~g} \mathrm{plant}{ }^{-1}\right)$ were observed in corm soaking of 150ppm $\mathrm{GA}_{3}\left(\mathrm{G}_{2}\right)$. It was followed by the 100ppmGA $\left(G_{1}\right)$. IAA treatments have recorded significantly higher growth parameters when compared to the control treatments which recorded the least growth parameters viz., plant height $(97.9 \mathrm{~cm})$, leaf length $(65.6 \mathrm{~cm})$, leaf area $\left(114.5 \mathrm{~cm}^{2}\right)$ and DMP (34.8 $\left.\mathrm{g} \mathrm{plant}^{-1}\right)$. The per se effect of leaf regulation practices were not significant in growth characters as these treatments were incorporated only after spike harvest. Among the interaction treatment, the highest mean growth parameters viz., plant height $(112.0 \mathrm{~cm})$, leaf length $(77.5 \mathrm{~cm})$, leaf area $\left(129.6 \mathrm{~cm}^{2}\right)$ and DMP $\left(41.8 \mathrm{~g} \mathrm{plant}^{-1}\right)$ were observed in the treatment of corm soaking of $150 \mathrm{ppm} \mathrm{GA}_{3}$ and harvesting of spikes with three leaves $\left(G_{2} \times L_{2}\right)$. The growth parameters observed in the interaction of 150ppm $\mathrm{GA}_{3}$ and harvesting spikeleaving all leaves and $150 \mathrm{ppm} \mathrm{GA}_{3}$ and clipping of leaves at $20 \mathrm{~cm}$ above the base were on par with $\mathrm{G}_{2} \times \mathrm{L}_{2}$.

Table 1: Effect of growth regulators and leaf regulation after spike harvest on growth and flowering in gladiolus

\begin{tabular}{|c|c|c|c|c|c|c|c|c|}
\hline Treatments & $\begin{array}{l}\text { Days taken for } \\
\text { corm sprouting }\end{array}$ & $\begin{array}{l}\text { Plant } \\
\text { height }\end{array}$ & $\begin{array}{l}\text { Leaf } \\
\text { length }\end{array}$ & \begin{tabular}{|c}
$\begin{array}{c}\text { Leaf area } \\
\mathrm{cm}^{2}\end{array}$ \\
\end{tabular} & $\begin{array}{c}\text { DMP } \\
\text { (g/ plant) }\end{array}$ & $\begin{array}{l}\text { Days taken for } \\
\text { spike emergence }\end{array}$ & $\begin{array}{l}\text { Spike } \\
\text { length }\end{array}$ & $\begin{array}{l}\text { Spike } \\
\text { weight }\end{array}$ \\
\hline \multicolumn{9}{|l|}{$G \times L$ Mean } \\
\hline $\mathrm{G}_{1} \times \mathrm{L}_{1}$ & 7.6 & 107.6 & 74.0 & 124.8 & 39.8 & 72.3 & 94.7 & 101.5 \\
\hline $\mathrm{G}_{1} \times \mathrm{L}_{2}$ & 7.7 & 108.2 & 74.4 & 125.5 & 40.0 & 72.8 & 95.3 & 102.1 \\
\hline $\mathrm{G}_{1} \times \mathrm{L}_{3}$ & 7.7 & 108.0 & 74.3 & 125.3 & 39.9 & 72.6 & 95.1 & 101.9 \\
\hline $\mathrm{G}_{2} \times \mathrm{L}_{1}$ & 7.0 & 110.9 & 76.7 & 128.3 & 41.4 & 70.2 & 98.3 & 104.5 \\
\hline $\mathrm{G}_{2} \times \mathrm{L}_{2}$ & 7.1 & 112.0 & 77.5 & 129.6 & 41.8 & 70.9 & 99.3 & 105.5 \\
\hline $\mathrm{G}_{2} \times \mathrm{L}_{3}$ & 7.0 & 110.3 & 76.4 & 127.7 & 41.2 & 69.8 & 97.8 & 103.9 \\
\hline $\mathrm{G}_{3} \times \mathrm{L}_{1}$ & 9.2 & 100.5 & 68.0 & 117.2 & 36.2 & 78.0 & 86.9 & 95.2 \\
\hline $\mathrm{G}_{3} \times \mathrm{L}_{2}$ & 9.1 & 99.5 & 67.3 & 116.1 & 35.9 & 77.3 & 86.0 & 94.3 \\
\hline$G_{3} \times L_{3}$ & 9.2 & 100.7 & 68.2 & 117.5 & 36.3 & 78.2 & 87.0 & 95.4 \\
\hline $\mathrm{G}_{4} \times \mathrm{L}_{1}$ & 8.4 & 104.4 & 71.3 & 121.5 & 38.2 & 75.4 & 91.1 & 98.7 \\
\hline $\mathrm{G}_{4} \times \mathrm{L}_{2}$ & 8.4 & 103.7 & 70.8 & 120.6 & 37.9 & 74.9 & 90.5 & 98.0 \\
\hline $\mathrm{G}_{4} \times \mathrm{L}_{3}$ & 8.5 & 105.2 & 71.8 & 122.3 & 38.4 & 76.0 & 91.8 & 99.4 \\
\hline$G_{5} \times L_{1}$ & 10.1 & 98.1 & 65.8 & 114.7 & 34.9 & 81.7 & 83.9 & 93.1 \\
\hline $\mathrm{G}_{5} \times \mathrm{L}_{2}$ & 10.0 & 98.0 & 65.7 & 114.6 & 34.9 & 81.6 & 83.8 & 93.0 \\
\hline $\mathrm{G}_{5} \times \mathrm{L}_{3}$ & 10.0 & 97.6 & 65.4 & 114.2 & 34.7 & 81.3 & 83.5 & 92.7 \\
\hline $\mathrm{CD}(\mathrm{P}=0.05)$ & 0.7 & 2.84 & 2.46 & 3.01 & 1.46 & 2.80 & 3.23 & 2.51 \\
\hline \multicolumn{9}{|l|}{ G Mean } \\
\hline $\mathrm{G}_{1}$ & 7.7 & 107.9 & 74.2 & 125.2 & 39.9 & 72.6 & 95.0 & 101.8 \\
\hline $\mathrm{G}_{2}$ & 7.0 & 111.0 & 76.9 & 128.5 & 41.4 & 70.3 & 98.4 & 104.6 \\
\hline $\mathrm{G}_{3}$ & 9.2 & 100.3 & 67.8 & 116.9 & 36.2 & 77.8 & 86.6 & 95.0 \\
\hline $\mathrm{G}_{4}$ & 8.4 & 104.4 & 71.3 & 121.5 & 38.2 & 75.4 & 91.1 & 98.7 \\
\hline $\mathrm{G}_{4}$ & 10.0 & 97.9 & 65.6 & 114.5 & 34.8 & 81.5 & 83.7 & 92.9 \\
\hline$C D$ & 0.4 & 1.56 & 1.36 & 1.65 & 0.80 & 1.54 & 1.78 & 1.38 \\
\hline \multicolumn{9}{|l|}{ L Mean } \\
\hline $\mathrm{L}_{1}$ & 8.5 & 104.3 & 71.2 & 121.3 & 38.1 & 75.5 & 91.0 & 98.6 \\
\hline $\mathrm{L}_{2}$ & 8.5 & 104.3 & 71.2 & 121.3 & 38.1 & 75.5 & 91.0 & 98.6 \\
\hline $\mathrm{L}_{3}$ & 8.5 & 104.4 & 71.2 & 121.4 & 38.1 & 75.6 & 91.0 & 98.7 \\
\hline $\mathrm{CD}(\mathrm{P}=0.05)$ & NS & NS & NS & NS & NS & NS & NS & NS \\
\hline $\begin{array}{l}\text { Corm soaking } \\
\text { G1-GA3@100 p } \\
\text { G2-GA3@150p }\end{array}$ & Gb & $\begin{array}{l}\text { AA@10 } \\
\text { AA@15 } \\
\text { Control }\end{array}$ & & & & 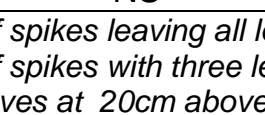 & bass & \\
\hline
\end{tabular}


Among all the interaction treatments, the lowest growth in terms of plant height $(97.6 \mathrm{~cm})$, leaf length $(65.4 \mathrm{~cm})$, leaf area $\left(114.2 \mathrm{~cm}^{2}\right)$ and DMP (34.7 $\mathrm{g} \mathrm{plant}^{-1}$ ) was observed in $\mathrm{G}_{2} \times \mathrm{L}_{2}$ which was on par with $\mathrm{G}_{2} \times \mathrm{L}_{1}$ and $\mathrm{G}_{2} \times \mathrm{L}_{3}$. Enhancement in growth parameters observed due to the application of $\mathrm{GA}_{3}$ might be due to its influence in early conversion of reserve carbohydrates that activated early sprouting of corms as evident by Priyanka and Saravanan (2019) in gladiolus due to $\mathrm{GA}_{3}$ application. The enhancement in cell elongation due to application of $\mathrm{GA}_{3}$ would have contributed for increased plant height, leaf area and dry matter production. Increase in number of leaves might be due to gibberellins cause stem elongation which results from rapid elongation of internodes due to cell division and cell elongation leading to the production of more number of leaves as reported by Padmalatha et al. (2013) and Sable et al. (2015) in gladiolus. Similar results have been reported by Patel et al.,(2013). The spike emergence is an indicator for the plant to attain its maximum growth. The earliest spike emergence on 70.9 days was observed in treatment combination $\mathrm{G}_{2} \times \mathrm{L}_{2}$. The spike emergence was significantly late in control treatment $\mathrm{G}_{5} \times \mathrm{L}_{3}$ (81.3 days). This could be due to early emergence of corms and early completion of vegetative phase, augmented by the $\mathrm{GA}_{3}$ influenced rapid cell division cell and elongation, in reducing the juvenile period of plants as reported by Wagh et al. (2012).

\section{Flowering and spike yield characters}

The flowering characters in Sarala were significantly influenced due to per se effect of growth regulators only as the per se effect of leaf regulation practices begin only after adoption of treatments at spike harvest stage (Table 1and 2). However, significant differences were observed in interaction treatment due to the influence of growth regulators. The maximum spike length of $99.3 \mathrm{~cm}$ was observed in treatment combination $\mathrm{G}_{2} \times \mathrm{L}_{2}$ which wason par with $\mathrm{G}_{2} \times \mathrm{L}_{1}(98.3 \mathrm{~cm})$ and $\mathrm{G}_{2} \times \mathrm{L}_{3}(97.8 \mathrm{~cm})$. The least spike length of $83.5 \mathrm{~cm}$ was recorded in control treatment.The maximum spike weight of $105.5 \mathrm{~g}$ was observed in treatment combination $\mathrm{G}_{2} \times \mathrm{L}_{2}$ which wason par with $\mathrm{G}_{2} \times \mathrm{L}_{1}(104.5 \mathrm{~g})$ and $\mathrm{G}_{2} \times \mathrm{L}_{3}(103.9 \mathrm{~g})$. Increase in spike length in treatment may be attributed due to the fact that optimum level of GA3 promoted the efficacy of plants in terms of photosynthetic activity, enhanced uptake of nutrients and their translocation, better partitioning of assimilates into reproductive parts. These results are in conformity with the findings of Tawar et al. (2007) and Chopde et al. (2013). The highest length of rachiswas observed in interaction of $\mathrm{G}_{2} \times \mathrm{L}_{2}(68.1 \mathrm{~cm})$ which wason par with $\mathrm{G}_{2} \times \mathrm{L}_{1}$ $(67.4 \mathrm{~cm})$ and $G_{2} \times L_{3}(67.1 \mathrm{~cm})$. The least rachis length was recorded in control treatment (55.6 $\mathrm{cm})$. The rachis length was enhanced due to increase in number of florets per spike due to the treatments. The least diameter of floret recorded in control treatment $(7.03 \mathrm{~cm})$ was on par with other interactions $\mathrm{G}_{5} \times \mathrm{L}_{2}(7.06 \mathrm{~cm})$ and $\mathrm{G}_{5} \times \mathrm{L}_{1}$ $(7.06 \mathrm{~cm})$. The first floret opening observed in treatment of $\mathrm{G}_{2} \times \mathrm{L}_{2}$ (82.4 days)wassignificantly earliest and it was on par with the treatments $\mathrm{G}_{2} \times \mathrm{L}_{1}$ and $\mathrm{G}_{2} \times \mathrm{L}_{3}$ as these treatments include150 ppm $\mathrm{GA}_{3}$. The highest diameter of floretwas observed in treatment of $\mathrm{G}_{2} \times \mathrm{L}_{2}(8.75 \mathrm{~cm})$ wason par with $\mathrm{G}_{2} \times \mathrm{L}_{1}(8.66 \mathrm{~cm})$ and $\mathrm{G}_{2} \times \mathrm{L}_{3}(8.62 \mathrm{~cm})$ as these treatments include150 ppm GA $\mathrm{G}_{3}$. The first floret open was significantly late in control treatment $\mathrm{G}_{5} \times \mathrm{L}_{3}$ (91.1 days) which was on par with other control treatment $\mathrm{G}_{5} \times \mathrm{L}_{2}$ (91.5 days) and $\mathrm{G}_{5} \times \mathrm{L}_{1}$ (91.6 days). Earliness in flowering observed in gladiolus by the application of $\mathrm{GA}_{3}$ treatments might be due to increase in endogenous level of $\mathrm{GA}_{3}$ as well as increase in respiration powered by the enhanced carbohydrates in the shoots, which resulted in early flowering. The findings are in accordance with the findings of Sudhakar and Ramesh Kumar (2012) in gladiolus.

The highest number of spike yield per plant was observed with $\mathrm{G}_{2} \times \mathrm{L}_{2}$ (1.01) which wason par with $G_{2 \times} L_{1}$ (1.00) and $G_{2} \times L_{3}(1.00)$. The least number of 0.68 spike per plant was recorded in control treatments $\mathrm{G}_{5} \times \mathrm{L}_{3}, \mathrm{G}_{5} \times \mathrm{L}_{2}$ and $\mathrm{G}_{5} \times \mathrm{L}_{1}$. The increased spike yield, observed in $\mathrm{GA}_{3}$ treatments, might be due to the maximum number of leaves and leaf area that contributed for highest growth rate and more photosynthate accumulation that enhanced the spike growth. Reduction in number of spikes per plant observed in control treatment was due to lack of enough growth. Similar views have also been expressed by Kumar and Singh (2005) and Chopde et al. (2013) in gladiolus. The maximum of 1.01 marketable spikes per plant was observed in treatment of $\mathrm{G}_{2} \times \mathrm{L}_{2}$. Theleast marketable spikes per plant (0.62) was recorded in control treatment $\left(\mathrm{G}_{5} \times \mathrm{L}_{3}\right)$. 
Table 2: Effect of growth regulators and leaf regulation after spike harvest on flowering and spike yield in gladiolus

\begin{tabular}{|c|c|c|c|c|c|c|c|c|}
\hline Treatments & $\begin{array}{l}\text { Rachis } \\
\text { length }\end{array}$ & $\begin{array}{c}\text { Floret } \\
\text { diameter }\end{array}$ & $\begin{array}{l}\text { Days taken } \\
\text { for first floret } \\
\text { open }\end{array}$ & $\begin{array}{l}\text { Spike } \\
\text { yield / } \\
\text { plant }\end{array}$ & $\begin{array}{l}\text { Marketable } \\
\text { Spikes per } \\
\text { plant }\end{array}$ & $\begin{array}{c}\text { Corm } \\
\text { diameter }\end{array}$ & $\begin{array}{l}\text { No. of } \\
\text { corms / } \\
\text { plant }\end{array}$ & $\begin{array}{l}\text { Corm } \\
\text { weight } \\
\text { (g) }\end{array}$ \\
\hline \multicolumn{9}{|l|}{$G \times L$ Mean } \\
\hline $\mathrm{G}_{1} \times \mathrm{L}_{1}$ & 64.6 & 8.27 & 83.3 & 0.94 & 0.92 & 2.96 & 1.76 & 23.3 \\
\hline$G_{1} \times L_{2}$ & 65.0 & 8.32 & 83.9 & 0.95 & 0.92 & 3.12 & 1.86 & 24.4 \\
\hline $\mathrm{G}_{1} \times \mathrm{L}_{3}$ & 64.8 & 8.31 & 83.7 & 0.95 & 0.92 & 2.86 & 1.70 & 22.7 \\
\hline $\mathrm{G}_{2} \times \mathrm{L}_{1}$ & 67.4 & 8.66 & 81.5 & 1.00 & 1.00 & 3.15 & 1.88 & 24.7 \\
\hline $\mathrm{G}_{2} \times \mathrm{L}_{2}$ & 68.1 & 8.75 & 82.4 & 1.01 & 1.01 & 3.25 & 1.94 & 25.4 \\
\hline $\mathrm{G}_{2} \times \mathrm{L}_{3}$ & 67.1 & 8.62 & 81.1 & 1.00 & 1.00 & 3.05 & 1.82 & 24.0 \\
\hline $\mathrm{G}_{3} \times \mathrm{L}_{1}$ & 58.4 & 7.41 & 88.2 & 0.82 & 0.73 & 2.65 & 1.57 & 21.2 \\
\hline $\mathrm{G}_{3} \times \mathrm{L}_{2}$ & 57.8 & 7.34 & 87.4 & 0.81 & 0.72 & 2.75 & 1.63 & 21.9 \\
\hline $\mathrm{G}_{3} \times \mathrm{L}_{3}$ & 58.5 & 7.43 & 88.4 & 0.82 & 0.73 & 2.52 & 1.49 & 20.3 \\
\hline $\mathrm{G}_{4} \times \mathrm{L}_{1}$ & 61.7 & 7.87 & 86.1 & 0.88 & 0.83 & 2.73 & 1.62 & 21.7 \\
\hline $\mathrm{G}_{4} \times \mathrm{L}_{2}$ & 61.3 & 7.82 & 85.5 & 0.88 & 0.82 & 2.85 & 1.69 & 22.6 \\
\hline $\mathrm{G}_{4} \times \mathrm{L}_{3}$ & 62.2 & 7.93 & 86.7 & 0.89 & 0.83 & 2.62 & 1.56 & 21.0 \\
\hline $\mathrm{G}_{5} \times \mathrm{L}_{1}$ & 55.9 & 7.06 & 91.6 & 0.76 & 0.65 & 2.31 & 1.36 & 18.9 \\
\hline$G_{5} \times L_{2}$ & 55.9 & 7.06 & 91.5 & 0.76 & 0.64 & 2.42 & 1.43 & 19.7 \\
\hline $\mathrm{G}_{5} \times \mathrm{L}_{3}$ & 55.6 & 7.03 & 91.1 & 0.76 & 0.64 & 2.08 & 1.22 & 17.3 \\
\hline $\mathrm{CD}(\mathrm{P}=0.05)$ & 2.60 & 0.36 & 2.48 & 0.055 & 0.082 & 0.09 & 0.05 & 0.61 \\
\hline \multicolumn{9}{|l|}{ G Mean } \\
\hline $\mathrm{G}_{1}$ & 64.8 & 8.30 & 83.6 & 0.95 & 0.92 & 2.98 & 1.77 & 23.5 \\
\hline $\mathrm{G}_{2}$ & 67.5 & 8.67 & 81.7 & 1.00 & 1.00 & 3.15 & 1.88 & 24.7 \\
\hline $\mathrm{G}_{3}$ & 58.2 & 7.39 & 88.0 & 0.81 & 0.73 & 2.64 & 1.57 & 21.2 \\
\hline $\mathrm{G}_{4}$ & 61.7 & 7.87 & 86.1 & 0.88 & 0.83 & 2.73 & 1.62 & 21.8 \\
\hline $\mathrm{G}_{4}$ & 55.8 & 7.05 & 91.4 & 0.76 & 0.64 & 2.27 & 1.34 & 18.6 \\
\hline$C D$ & 1.43 & 0.20 & 1.36 & 0.030 & 0.045 & 0.05 & 0.03 & 0.33 \\
\hline \multicolumn{9}{|l|}{ L Mean } \\
\hline $\mathrm{L}_{1}$ & 61.6 & 7.86 & 86.2 & 0.88 & 0.82 & 2.76 & 1.64 & 22.0 \\
\hline $\mathrm{L}_{2}$ & 61.6 & 7.86 & 86.1 & 0.88 & 0.82 & 2.88 & 1.71 & 22.8 \\
\hline$L_{3}$ & 61.6 & 7.86 & 86.2 & 0.88 & 0.82 & 2.63 & 1.56 & 21.1 \\
\hline $\mathrm{CD}(\mathrm{P}=0.05)$ & NS & NS & NS & NS & NS & 0.04 & 0.02 & 0.274 \\
\hline
\end{tabular}

\section{Corm Characters}

The corm characters were significantly influenced by the growth regulators as well as the leaf regulation practices (Table 2). Among the growth regulators, the highest mean corm diameter $(3.15 \mathrm{~cm})$, number of corms per plant (1.88) and corm weight (24.73g) were recorded with $150 \mathrm{ppm} \mathrm{GA}_{3}\left(\mathrm{G}_{2}\right)$ followed by $100 \mathrm{ppm}$ $\mathrm{GA}_{3}\left(\mathrm{G}_{1}\right)$. Among the leaf regulation treatments, the highest mean corm diameter $(2.88 \mathrm{~cm})$, number of corms per plant (1.71) and corm weight $(22.84 \mathrm{~g})$ were recorded when the spikes were harvested along with three leaves $\left(L_{2}\right)$ and it was followed by the treatments where spikes was harvested leaving all the leaves intact with plant $\left(L_{1}\right)$. Clipping of leaves at $20 \mathrm{~cm}$ above the base $\left(L_{3}\right)$ has resulted poor performance in terms of the corm growth. Among all the interaction treatments, the maximum corm diameter $(3.25 \mathrm{~cm})$, number of corms per plant (1.94) and corm weight (25.4g) were observed with $150 \mathrm{ppm} \mathrm{GA}_{3}$ and harvesting spikes with three leaves $\left(\mathrm{G}_{2} \times \mathrm{L}_{2}\right)$. The least corm diameter $(2.08 \mathrm{~cm})$, number of corms per plant $(1.22)$ and corm weight $(17.3 \mathrm{~g})$ were recorded with control treatment with cutting leaves at $20 \mathrm{~cm}$ above the base. Enhancement in the corm growth observed in the treatment $G_{2} \times L_{2}$ might be attributed by the influence of $\mathrm{GA}_{3}$ coupled with the early initiation carbohydrate apportioning form source leaves to sinks, the corms, due to the stress signals activated by harvesting of spikes along with three leaves. Whereas, when clipping of leaves at $20 \mathrm{~cm}$ above the base $\left(L_{3}\right)$ was done, it might have caused more stress and reduced the source content needed for sink apportioning that caused reduction in corm growth. These results on leaf clipping are in line with the reports of Memon et al.(2009). 
It could be concluded that the corm dipping of $150 \mathrm{ppmGA}_{3}$ and harvesting of spikes along with three leaves could be adopted to

\section{REFERENCES}

Chopde N, Gonge V.S, and Warade A.D. (2013) Influence of growth regulators on gladiolus varieties.Journal of Agriculture Research and Technology 38(3):369-374.

Jinegh Patel, Patel, H.C., Chavda, J.C. and Saiyad, M.Y. (2010) Effect of plant growth regulators on flowering and yield of Gladiolus Grandiflorus L. cv. American beauty. Asian Journal of Horticulture 5(2): 483-485.

Kumar, V. and Singh, R. P. (2005) Effect of soaking of mother corms with plant growth regulators on vegetative growth, flowering and corm production in gladiolus. Journal of Ornamental Horticulture 8(4): 306-308

Memon, N., Qasim M, Jaskani M. J., Ahmad R, Anwar R. (2009). Effect of various corm sizes on the vegetative, floral and corm yield attributes of gladiolus. Pakistan Journal of Agricultural Science 46:13-19.

Memon, N., Wahocho, N. A., Miano, T. F., and Leghari, M. H., (2016) Propagation of Gladiolus corms and cormels: A review, African Journal of Biotechnology 15(32), pp. 1699-1710.

Neha Chopde, Gonge, V.S. and Dalal, S.R. (2012) Growth flowering and corm production of gladiolus as influenced by foliar application of growth regulators. Plant archives 12(1): 41-46.

NHB, (2020) Horticulture Production Statistics.

Available at http://nhb.gov.in/statistics

/State Level/ 2015-

$16 \% 20$ (Final\%20Est.)_0.xlsx

Padmalatha, T., Reddy, G.S., Chandrasekhar, R., Shankar, A.S., and Chaturvedi A.

(2013) Effect of foliar spray of bioregulators on growth and flowering in gladiolus. Indian Journal of Agricultural Research 47(3):192199.

Panse, V.G. and Shukhatme, P.V. (1967) Statistical Methods for Agricultural Workers, ICAR, Krishi Bhawan, New Delhi.

Panwar, R.D., Sindhu, S. S., Sharma, J. R. and Saini, R.S. (2006).Effect ofgibberellic acid enhance the production of marketable spikes and good quality corms.

spray on growth, flowering, quality and yield of bulbs in tuberose. Haryana Journal of Horticultural Sciences 35: 253-255.

Patel, B.B., Desai, J.R., Patel, G.D. and Patel, H.F. (2013) Influence of foliar application of nitrogen and plant growth regulators on growth, flowering and corm production of gladiolus cv. American beauty. Bioinfolet Journal of Life Science 10(2): 415-417.

Priyanka, R. and Saravanan. S.S. (2019) Effect of plant growth regulators on flowering, corm and cormel parameters in gladiolus. International Journal of Chemical Studies 7(3): 4622-4625.

Rana,P., Kumar,J. and Kumar, M. (2005) Response of $\mathrm{GA}_{3}$, plant spacing and planting depth on growth, flowering and corm production in gladiolus. Journal of Ornamental Horticulture 8:41-44.

Sable, P.B., Ransingh, U.R. and Waskar, D.P.(2015) Effect of foliar application of plant growth regulators on growth and flower quality of gladiolus cv. 'H.B. Pitt'. Journal of Horticulture 2(3):141-143.

Sharma,J.R., Gupta, R.B. and Panwar. R.D. (2004) Growth flowering and corm production Gladiolus cv. Friendship as influenced by foliar application of nutrients and growth regulators. Journal of Ornamental Horticulture 7 (4): 154-158.

Sudhakar, M. And Rameshkumar, S.(2012) Effect on corm size and growth regulators on growth and flowering of Gladiolus cv. White Friendship. Indian Journal of Plant Science 1(3): 133-136.

Tawar, R.V., Sable, A.S. and Giri, M.D. (2003) Effect of growth regulators on growth and flowering of gladiolus $O$. J. Jester. Annals of Plant Physiology 17(2): 109-111.

Wagh.V.K., Chawla, S.L., Gaikwad, A.R., Parolekar, S.S. (2012) Effect of bulb size and $\mathrm{GA}_{3}$ on vegetative and floral characters of tuberose (Polianthes tuberose L.)Cvs. Prajwal and Calcutta Single.Progressive Horticulture 44(1):27-31. 